\title{
Analysis of water retention changes in selected lake-wetland catchments of West Polesie based on historical documents
}

\author{
Katarzyna Mięsiak-Wójcik \\ Hydrology Department, Faculty of Earth Sciences and Spatial Management, Maria Curie-Skłodowska University in Lublin, Kraśnicka 2cd, \\ 20-718 Lublin, Poland, e-mail: katarzyna.miesiakwojcik@umcs.pl
}

\begin{abstract}
The paper presents analysis results concerning changes in the range of areas of surface and transitional retention, here corresponding with wetlands, in two small lake catchments in the western part of West Polesie. The cartometric research was performed on maps covering the period from the $19^{\text {th }}$ to the early $21^{\text {st }}$ century. The analyses were referred to the modern state of investigation recorded on orthophotomaps in data bases disclosed in Geoportal Krajowy and in the Google Earth Pro application. Lake surface retention showed no substantial changes, and the differences result from the scale of maps used in the study, and therefore from the degree of detail of the presented objects. In the catchment of Lake Czarne Gościnieckie it occupied from 13.61 to 15.64\% of its area, and in the catchment of Lake Brzeziczno from 0.96 to $1.28 \%$. The greatest discrepancies in the area of wetlands result from the cartographic method of presentation, and generalisation of maps. In the catchment of Lake Czarne Gościnieckie, areas of transitional retention could be identified on 11 out of 13 maps, and in the catchment of Lake Brzeziczno on 12. In the case of the former catchment, transitional retention occupies from 17.35 to $34.00 \%$ of its area, and in the catchment of Brzeziczno from 4.81 to $24.00 \%$. Such different surface areas of wetlands measured on maps, however, do not signify evident tendencies for change. Over the last 200 years, no substantial changes occurred in the studied catchments regarding the range of surface waters and wetlands, as confirmed by field research conducted in the years 2006-2012. The quantity and quality of maps and the variability of their scales encourage a careful interpretation of obtained information. In such a case, it is necessary to supplement cartographic analyses with investigating procedures of map preparation, and also to collect written documents concerning the entire area.
\end{abstract}

Key words: lake-wetland catchments, forms of retention, archival maps, historical GIS

\section{Introduction}

In hydrology, retention is defined as the temporary containment of water in a catchment area (Dębski 1970; Gutry-Korycka 1997). Depending on the way and place of accumulation of water resources, it can be divided into two types: surface and subsurface. According to Dynowska (1993), a third type of retention should also be designated, namely transitional retention, defined as an intermediate phase of water retention (accumulation) between the zones of surface and subsurface retention. Areas of this type of retention are referred to as wetlands (Pieczyńska 1990; Hilbricht-Ilkowska 1993; Ilnicki 2002), because the organic sediments developing them are characterised by very high content of water, varying from 75 to $97 \%$ of their volume. As a result of this, they are often compared to retention reservoirs (Okruszko 1991) which through developing hydrological and biocoenotic feedbacks with the surrounding areas can constitute independently functioning objects (Brooks and Hayashi 2002; Brooks 2004, 2005). Many papers concerning wetlands emphasise their retention potential and very high importance in geographic space (Tobolski 2003; Oertli et al. 2005). According to Tobolski (2003) "peatlands are important, the best retention reservoirs with the most beneficial location, because they are created by forces of nature" and their retention properties should be subject to special attention, particularly in the case of changes in water relationships in a given area.

Even at the stage of early studies on the evolution of the lake and its catchment, the differentiation of areas of particular types of retention is based on individual hydrologic and genetic conditions (Churski 1988). Individual morphometric parameters of a lake, such as its surface area, depth, shape or shoreline, affect the course of processes occurring within the basin and its shores, among others growing over (terrestrialisation of the water surface), sedentation and sedimentation, and water 
level fluctuations in the lake (Ralska-Jasiewiczowa and Starkel 1988; Żurek 1990; Churski 1993; Chmielewski and Radwan 1996; Starkel et al. 1996; Lamentowicz 2005; Choiński 2007; Gałka 2007a, 2007b; Barabach 2012). Transformations of the range of particular forms of water retention, caused by the aforementioned cyclical natural processes, have been considerably strengthened by economic processes. The rate, and particularly direction of such changes, suggest a successive decrease in the wetland areas in Poland (Choiński 1997; Choiński and Madalińska 2002; Kowalewski 2003; Superson and Szwajgier 2003; Marszelewski and Adamczyk 2004; Czaja and Jańczak 2010; Marszelewski 2005; Marszelewski et al. 2011; Fabich and Kwidzińska 2012; Piasecki 2013; Kramkowski et al. 2014). These processes were primarily caused by intensive melioration works. In the period, new techniques of preparation of cartographic documentation were introduced. Their cartometric character allows for performing measurements on them for chronological and relatively accurate records of changes occurring in the environment.

The objective of this paper is the temporal-spatial analysis of changes in the range of particular forms of retention based on the available historical materials (mainly topographic maps) on the example of two lake catchments in the Łęczna-Włodawa Lakeland.

\section{Study area}

Man has been interfering with water relations in West Polesie for centuries (Wilgat et al. 1997). In the area of the Łęczna-Włodawa Lakeland - a region where water developed the primary parameters of the natural environment, extensive wetlands, impeded water outflow, and swampy shores of many lakes created difficult conditions for land management. Various hydrotechnical treatments aimed at drying excessively swampy land or changing water circulation. Economic activity largely disturbed the natural processes of development of particular forms of retention (Wilgat et al. 1997). In many cases it caused negative, often irreversible transformations in lake catchments (Mięsiak et al. 2005). Depending on the conducted works, the changes contributed to transformations of the lake basin and its shores. They also affected the quality and quantity of water (Churski 1988; Dembek et al. 2004). Their effect on lake catchments was both permanent and temporary (often only seasonal). Some of the activities could be controlled, while others were entirely uncontrollable and had unpredictable effects (Mięsiak et al. 2005; Mięsiak-Wójcik et al. 2014; Kowalewski 2012).

The analyses of changes in the surface area of retention forms covered catchments of Lakes Czarne Gościnieckie (51 $\left.{ }^{\circ} 31^{\prime} 47^{\prime \prime} \mathrm{N}, 22^{\circ} 52^{\prime} 36^{\prime \prime E}\right)$ and Brzeziczno

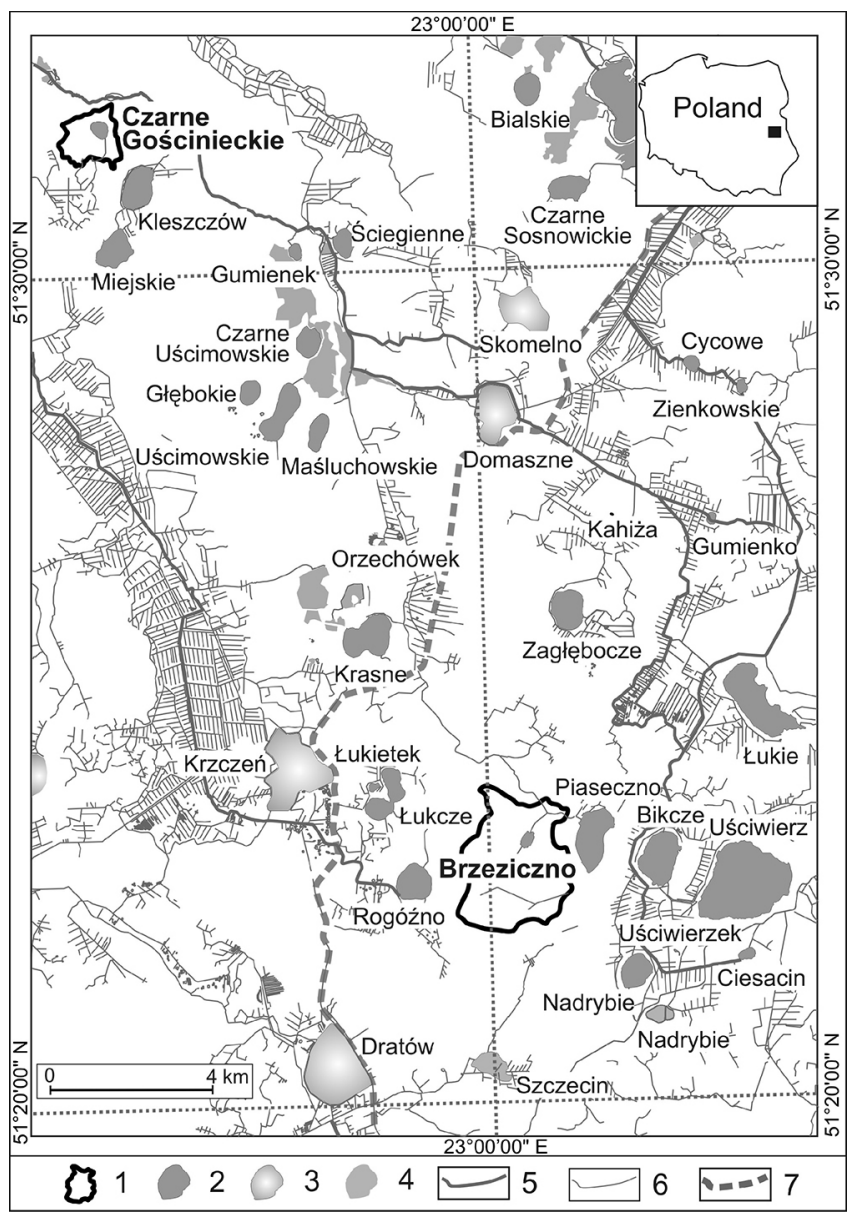

Fig. 1. Location of the studied catchments in West Polesie. Explanation: 1 - catchments under study, 2 - lakes, 3 - water reservoirs, 4 - ponds and overflows, 5 - larger streams, 6 - melioration ditches, 7 - Wieprz-Krzna Canal

$\left(51^{\circ} 23^{\prime} 04^{\prime \prime} \mathrm{N}, 23^{\circ} 00^{\prime} 32^{\prime \prime} \mathrm{E}\right)$, located in the western part of West Polesie (Fig. 1). Their selection was based on their common parameters such as: low degree of anthropogenic transformation (Michalczyk and Turczyński 1998) and considerable areas of wetlands surrounding the shallow lakes (Table 1). The catchments are also characterised by monotonous land relief (Table 1), shallow occurrence of layers of impermeable deposits such as silts and muds, as well as their original closeddrainage character. Such parameters favour the maintenance of permanent wetlands. Lakes and wetlands currently occupy $44.5 \%$ of the catchment area of Lake Czarne Gościnieckie, and $12.4 \%$ of the catchment area of Lake Brzeziczno. Wetlands surrounding the lakes are primarily peatlands with post lake genesis underlain with gyttja deposits (Borowiec 1990).

The analysed catchments differ in their size (surface area), lake density, swampiness, and contribution of anthropogenic forms of land use (Table 1). The catchment of Lake Czarne Gościnieckie includes no arable land or 
Table 1. Contemporary geographical characteristics of the studied lakes and their catchments according to BDOT10k database available at National Geoportal (GUGiK 2017) and on own field research

\begin{tabular}{|c|c|c|c|c|c|c|c|c|c|c|c|}
\hline \multirow{4}{*}{ Catchment } & \multicolumn{8}{|c|}{ Catchment morphometry and land use forms } & \multicolumn{3}{|c|}{ Lake morphometry } \\
\hline & \multirow{3}{*}{$\begin{array}{c}\text { Total } \\
\text { area } \\
{\left[\mathrm{hm}^{2}\right]}\end{array}$} & \multicolumn{3}{|c|}{ Altitude } & \multirow{3}{*}{$\begin{array}{l}\text { Mean } \\
\text { slope } \\
\text { [deg.] }\end{array}$} & Wetlands & Forests, & Waters & \multirow{3}{*}{$\begin{array}{c}\text { Mean } \\
\text { surf. area } \\
{\left[\mathrm{hm}^{2}\right]}\end{array}$} & \multirow{3}{*}{$\begin{array}{c}\text { Mean } \\
\text { depth } \\
{[\mathrm{m}]}\end{array}$} & \multirow{3}{*}{$\begin{array}{l}\text { Mean } \\
\text { elevation } \\
\text { [m a.s.l.] }\end{array}$} \\
\hline & & Max. & Min. & Mean & & vvetlanus & bushes & valers & & & \\
\hline & & & [m a.s.l.] & & & & {$\left[\mathrm{hm}^{2}\right]$} & & & & \\
\hline $\begin{array}{l}\text { Czarne } \\
\text { Gościnieckie }\end{array}$ & 82.80 & 161.33 & 152.00 & 153.92 & 3.14 & 24.98 & 67.24 & 11.83 & 11.83 & 1.0 & 152.00 \\
\hline Brzeziczno & 706.42 & 176.57 & 170.20 & 172.18 & 0.90 & 79.38 & 442.50 & 7.84 & 7.79 & 1.3 & 170.20 \\
\hline
\end{tabular}

building development. In the catchment of Lake Brzeziczno, anthropogenic forms of land use such as building development and arable land occupy a total of approximately one third of its surface area.

The high environmental values of the Lake Brzeziczno catchment provided the basis for the establishment of the peatland reserve "Lake Brzeziczno" in 1959. The reserve occupies an area of $87 \mathrm{hm}^{2}$, and covers the lake and the surrounding peatlands. The peatlands show a characteristic sequence: floating mat zone occupying water boundaries, transitional peatlands, and raised bogs located on the wetland boundaries. Lake Czarne Gościnieckie catchment, with a considerably higher contribution of natural areas, has not been covered by reserve protection so far owing to a high degree of fragmentation of land ownership.

\section{Materials and Methods}

Research on changes in the surface area of lakes and transformations of areas occupied by wetlands was performed based on 13 cartographic documents (Table 2). Ten of them are topographic maps and the remaining ones are thematic studies. It is a continuation of works initiated by the Author in 2004 (Mięsiak et al. 2005).

The analysis of the content of historical maps is a method commonly applied in tracing changes occurring in the geographic space (Cebrykow 2015; Czerny 2015; Ptak 2013), although it is increasingly being replaced by the techniques of aerial or satellite photography. Although it is the simplest way of documenting changes in the surface of hydrographic objects, the application of this research procedure should necessarily

Table 2. List of maps used in the study

\begin{tabular}{|c|c|c|c|}
\hline $\begin{array}{l}\text { Name of the map } \\
\text { /author/ }\end{array}$ & Scale & Year & $\begin{array}{l}\text { Source of cartographic materials and period of the } \\
\text { topographic surveys }\end{array}$ \\
\hline $\begin{array}{l}\text { Carte von West-Gallizien } \\
\text { /Antoni Mayer von Heldensfeld/ }\end{array}$ & $1: 172800$ & 1808 & $\begin{array}{c}\text { the map is a reduction of the military surveys }(1: 28 \text { 800) } \\
\text { performed in } 1801-1804\end{array}$ \\
\hline $\begin{array}{l}\text { Topograficzna karta Królestwa Polskiego } \\
\text { /Kwatermistrzostwo Generalne WP (KG WP)/ }\end{array}$ & $1: 126000$ & $1839-1843$ & $\begin{array}{l}\text { topographic surveys }(1: 42000) \text { performed in } 1822-1843 \\
\text { (Polesie region in 1833-1839); cartographic source for the } \\
\text { studied area was Carte von West-Gallizien by Heldensfeld }\end{array}$ \\
\hline $\begin{array}{l}\text { Karte des Westlichen Russland } \\
\text { /Königlich Preussische Landesaufnahme (KPL)/ }\end{array}$ & $1: 100000$ & 1914 & $\begin{array}{c}\text { based on Russian maps }(1: 21000,1: 42000,1: 84000 \text { and } \\
1: 126000) \text { from } 19 \text { th century }(1886-1893)\end{array}$ \\
\hline $\begin{array}{l}\text { Spezialkarte der österreichisch-ungarischen } \\
\text { Monarchie } \\
\text { /K.K. Militärgeographisches Institut (K.K. MGI)/ }\end{array}$ & $1: 75000$ & 1915 & $\begin{array}{l}\text { compilation of map sheets: Parczew B XXVIII (3370) and } \\
\text { Łęczna A XXVIII (3470), shows situation from } 1895\end{array}$ \\
\hline $\begin{array}{l}\text { Szczegółowa mapa Polski } \\
\text { Mojskowy Instytut Geograficzny (WIG)/ }\end{array}$ & $1: 25000$ & 1936 & $\begin{array}{c}\text { on the basis of annexation maps - Russian topographical } \\
\text { surveys from 1885-1892 }\end{array}$ \\
\hline $\begin{array}{l}\text { Mapa taktyczna Polski } \\
\text { /Wojskowy Instytut Geograficzny (WIG)/ }\end{array}$ & $1: 100000$ & 1938 & based on WIG maps (1:25 000) from 1936 \\
\hline $\begin{array}{l}\text { Topograficheskaia karta RKKA } \\
\text { /Genshtab RKKA/ }\end{array}$ & $1: 50000$ & 1941 & $\begin{array}{l}\text { based on topographic surveys }(1: 21000) \text { in } 1886-1887 \\
\text { supplemented with WIG maps }(1: 100000) \text { issued in the } \\
\text { years 1936-1938; update: August-December } 1940\end{array}$ \\
\hline AMS M651 (GSGS 4416) Poland & $1: 100000$ & 1944 & $\begin{array}{c}\text { compilation of WIG maps }(1: 100000) \text { and British Intelligence } \\
\text { Reports from } 1943\end{array}$ \\
\hline $\begin{array}{l}\text { Mapa obrębowa powiatów ("obrębówka") } \\
\text { /Zarząd Topograficzny Sztabu Gen. (ZTSG)/ }\end{array}$ & $1: 25000$ & 1960 & $\sim 1957$ \\
\hline \multirow{2}{*}{$\begin{array}{l}\text { Szczegółowa mapa geologiczna Polski } \\
\text { /Państwowy Instytut Geologiczny (PIG)/ }\end{array}$} & \multirow[t]{2}{*}{$1: 50000$} & 1979 & field geological surveys: 1973-1975 \\
\hline & & 1981 & field geological surveys: 1971-1977 \\
\hline $\begin{array}{l}\text { Topograficzna mapa Polski } \\
\text { /Główny Urząd Geodezji i Kartografii (GUGiK)/ }\end{array}$ & $1: 10000$ & 1984 & shows topographic situation from 1977 \\
\hline $\begin{array}{l}\text { Wojskowa mapa topograficzna } \\
\text { /Zarząd Topograficzny Sztabu Gen. (ZTSG)/ }\end{array}$ & $1: 50000$ & 1987 & shows topographic situation from 1984 \\
\hline $\begin{array}{l}\text { Mapa hydrograficzna Polski } \\
\text { /Główny Urząd Geodezji i Kartografii (GUGiK)/ }\end{array}$ & $1: 50000$ & 2006 & hydrographic field surveys: 2005 \\
\hline
\end{tabular}


involve familiarisation with the methodology and technology of preparation of the materials (Graf et al. 2008; Panecki 2015). Information obtained from the analysis of historical maps should be approached carefully and if possible, verified with written documents.

Maps and other archival documents permit a relatively thorough tracing of surface transformations of retention in the area of West Polesie only for the period of the last 200-250 years. Part of the oldest available cartographic sources, e.g. Mappa szczegulna woiewodztwa lubelskiego (Detailed map of the Lublin Voivodeship) at a scale of 1:225 000 by Karol de Perthées (1806), is only a draft from the cartographic point of view (Buczek 1963; Jop 1998). Lack of triangulation calculations in its preparation, and primary use of itineraries results in among others substantial distortion of distances, disqualifying them from further detailed spatial analyses. In the case of analysis of small changes in comparison to the size of the catchment, large-scale $(1: 10000)$ and medium-scale maps (1:20 000-1:300 000) are the most suitable. Maps used for analyses were prepared in different periods and scales. To present changes occurring as a result of human activity, surface retention was divided into natural and anthropogenic. Considering the chronology of cartographic documents, five interpretation periods were designated.

The first half of the $19^{\text {th }}$ century is represented by two cartographic sources: (i) Carte von West-Gallizien (Map of western Galicia) at a scale of 1:172 800 prepared by Antoni baron Mayer von Heldensfeld in the years 1801-1804, and issued four years later (Heldensfeld 1808). This map was described in detail by Sawicki (1928), and (ii) Topograficzna karta Królestwa Polskiego (Topographic map of the Polish Kingdom) at a scale of 1:126000 - one of the most outstanding achievements of Polish military cartography of the $19^{\text {th }}$ century (KG WP 1839-1846).

Analyses of the maps from second half of the $19^{\text {th }}$ century were based on: (i) Karte des Westlichen Russland (Map of the Western Russia) developed at a scale of 1:100 000 presenting the topographic situation from 1886-1893, but issued in 1914 by Königlich Preussische Landesaufnahme (KPL 1914), and (ii) Spezialkarte der österreichisch-ungarischen Monarchie 1:75 000 (Special map of the Austro-Hungarian monarchy) published in Vienna by the Kaiserlich-Königlich Militärgeographische Institut in 1915, but showing topographic situation from 1895 (K.K. MGI 1915).

The state of the water environment in the following five decades covering the first half of the $20^{\text {th }}$ century was analysed the basis of information included in: $(i)$ Szczegółowa mapa Polski (Detailed map of Poland) at a scale of 1:25 000, issued in 1936, and (ii) Mapa taktyczna Polski (Tactical map of Poland) issued in 1938 at a scale of 1:100 000. These maps were issued by Wojskowy Instytut Geograficzny - WIG (Military Geographic Institute), and constitute a valuable source of cartographic information about Poland during the inter-war period (WIG 1936, 1938). The aforementioned Polish maps were used by the Soviet invaders to prepare the Topograficheskaia karta RKKA (Topographic map of the General Staff of the Red Army), modernised by their military topographic services and published in 1941 at a scale of 1:50 000 (Genshtab RKKA 1941). The map issued by the Army Map Service US Army at a scale of 1:100 000 (AMS 1944), also prepared based on pre-war maps of WIG, likewise comes from that period.

The analyses of surface areas of forms of surface and transitional retention in the second half of the $20^{\text {th }}$ century applies: (i) Mapa obrębowa powiatów (Precinct map of counties) issued in 1960 at a scale of 1:25 000 (ZTSG 1960). This map was the first post-war map designated for economic, not military, purposes. In spite of certain drawbacks (among others purposely introduced linear, angular, and surface deformations), it has constituted the only available map for civil purposes for many years. Maps from this period much more detailed in terms of cartometrics include: (ii) Topograficzna mapa Polski (Topographic map of Poland) at a scale of 1:10 000 issued by the Head Office of Geodesy and Cartography in 1984 (GUGiK 1984), and (ii) Wojskowa mapa topograficzna (Military topographic Map) at a scale of 1:50 000, published by the Polish General Staff in 1987 (ZTSG 1987). The former is the most accurate (the most detailed) among the analysed printed topographic maps.

Tracing changes in forms of retention information from thematic maps at a scale of 1:50 000 was also applied. One of such sources was Szczegółowa mapa geologiczna Polski (Detailed Geological Map of Poland), whose sheets used in this study were issued in the years 1979-1981 (PIG). This map was particularly useful for determination of the spatial range of transitional retention based on the analysis of the lithology, genesis, and stratigraphy of formations (Liszkowski 1979a,b; Stochlak 1979a,b; Buraczyński and Wojtanowicz 1981a,b). These works also show the geological structure of the subsurface zone down to $2 \mathrm{~m}$, with consideration of information presented in vertical geologi$\mathrm{cal}$ and synthetic profiles. Another thematic map used for the analyses was Mapa hydrograficzna Polski (Hydrographic map of Poland) issued in 2006, constituting a source of information from the early $21^{\text {st }}$ century (GUGiK 2006).

In addition to information obtained from maps and data bases, the analysis of transformation of the studied areas was enriched with data obtained from written documents. Particular attention was paid to descriptions of 
issues related to works involving the preparation of maps for printing (Krassowski 1974, 1978), and historical materials referring to the analysed catchments. Only four documents containing references to the surface area or names of the studied lakes were found (Jop 1998; Wilgat 1954). The oldest lustrative documents from the $16^{\text {th }}$ and $17^{\text {th }}$ century only describe Lake Czarne Gościnieckie, located at the main route connecting Kraków with Vilnius at that time. The lake was called Ploczicze (Wyczański 1959) or Płocicin (Oprawko and Schuster 1962). According to Jop (1998), the name Płocice was the most commonly used name in the period from the $15^{\text {th }}$ to the $18^{\text {th }}$ century. Both lustrative documents also mention the surface area of the lake. According to the census from 1565, it amounted to 2 depths, and in 1661 only one depth ( 1 depth $\sim 4-5 \mathrm{hm}^{2}$ ). According to field mapping of the lakes of the Łęczna-Włodawa Lakeland performed in the years 1948-1952 (Wilgat 1954), Lake Czarne Gościnieckie had an area of $11.6 \mathrm{hm}^{2}$, and Lake Brzeziczno was not measured because of excess water maintained in the peatlands.

All data for further analyses were obtained by means of screen digitalisation after calibration of scans of printed (paper) maps in accordance with the rules presented in papers concerning broadly defined historical GIS (Affek 2013; Kuna 2015). Georeference was ascribed to historical maps based on modern maps disclosed on the National Geoportal website [GUGiK 2017] by means of software by Esri and Goldensoftware.

\section{Results and Discussion}

The increasingly common application of GIS techniques in research on environmental transformations in the historical context (historical GIS) allowed for, on the one hand, the assessment of the quality of the research material, and on the other hand for formulating conclusions. Assuming only quantitative assessment of the materials, the analysed area seems to be well documented cartographically. However, referring to documents describing the history of preparation of particular maps reveals several reasons for being very careful when drawing conclusions. The primary reason is the commonly applied technique of copying topographic information from earlier maps to new ones. Due to unfavourable conditions for providing economic activity, the area of West Polesie has been weakly investigated for many centuries. Numerous wetlands developing in endorheic depressions, low slope inclinations, and specific geological structure hindered the development of agriculture. Excess water also discouraged the establishment of settlements, and therefore the road network. The aforementioned reasons resulted in civilizational backwardness, also resulting in poor registration of the space on maps. The increased interest of military topographic services in the analysed region should be associated with the period of Poland's partitions and the military conflicts of the participating countries (Affek 2013).

Due to the lack of reference to the quality of the analysed cartographic documents in many documents presenting spatial changes in the aquatic environment, the manner of preparation of two maps by military topographic services is briefly discussed below, namely: Topograficzna karta Królestwa Polskiego (Topographic map of the Polish Kingdom) and Szczegółowa mapa Polski (Detailed map of Poland). The release dates of both these maps are separated by a nearly 100 -years . Information on their method of preparation, determined by the contemporary technological possibilities, and often also political and socio-economic factors, provides the basis for an accurate interpretation of the content and usefulness of maps for further environmental analyses.

The first of the aforementioned maps was prepared for the administrative and military purposes of the Polish Kingdom. Its preparation was entrusted to the cartographers of the Quartermaster Staff of the Polish Army (Krassowski 1978). The cartographic source enabling its creation were filed works by Antoni von Heldensfeld from the years 1801-1804, done without triangulation measurements. Cartographic works needed for preparation of this map covered: triangulation measurements based on mathematical basics, uniform for the entire country, a topographic survey performed on the basis of previously measured geodesic points, and cartographic works resulting in the release of a detailed and uniform map for the entire country. For economic and political reasons, the most expensive and time-consuming triangulation works were not performed throughout the country. They were limited to several important regions (Olszewicz 1921; Krassowski 1978). The area of West Polesie was only mapped after the defeat of the November Uprising (1830). Work on the map was then taken over by the Russian Corps of Topographical Engineers, conducted in the years 18321843. Only places important for military purposes were measured instrumentally. The remaining field points and spaces were introduced based on approximate visual estimation (Olszewicz 1921). All sheets of the map were released were dated 1839 , although actually in 1843. It can be therefore be assumed that the sheets of map used for analyses of lake catchments depict the topographic situation from the years 1832-1939.

On the Topograficzna karta Królestwa Polskiego, in spite of its scale (1:126 000) and application of a single colour, objects of surface retention and wetlands are visible. For military purposes it was more important to mark the transport routes, distance between settle- 
ments, and their location in relation to one another. Precise determination of geographical coordinates was of less importance. Measurements in built-up areas were performed instrumentally, and unimportant military topographic surveys were performed rather vaguely. Therefore, the area of the Lake Brzeziczno catchment, located far from the main roads and settlements at the time, shows more substantial distortions than that of the Lake Czarne Gościnieckie catchment, located along an important historical transport route.

Another document worth analysing - Szczegółowa mapa Polski (1:25 000) - was prepared on the basis of earlier Russian cartographic documentation from 1887. The sheets were only partially prepared, as suggested by the index included in the WIG maps catalogue. It resulted from rush (among others names of topographic objects were left in the Russian language) and low degree of accuracy of the basic material. Some sheets were also released with an annotation "...not suitable for cartometric purposes” (Krassowski 1974).

The aforementioned comments and reservations encourage caution in drawing conclusions, particularly in the case of research on the range of hydrographic objects, subject to the most dynamic changes in time and space. The discussion should also include the fact that both of the aforementioned maps as well as other maps, particularly those issued in the inter-war period by WIG, are among the best contemporary cartographic documents prepared for military purposes in the world (Krassowski 1974, 1978). Their usefulness for environmental and historical analyses was also confirmed by Polish authors, among others Szady (2008) and Panecki (2014).

GIS techniques, commonly applied in the $21^{\text {st }}$ century, allowing for the comparison of spatial information recorded in archival maps, permit the assessment of changes occurring in the environment (Szady 2008). The results of analyses of cartographic documents are presented below in a chronological order, grouping them by analysed lake catchments.

\section{Changes in areas of retention forms in Lake Czarne Gościnieckie catchment}

The map Carte von West-Gallizien released in 1808 shows areas of surface retention occupying almost half $\left(40.20 \mathrm{hm}^{2}\right)$ of the total area of the analysed lake catchment, recording no transitional retention within this area (Fig. 2A, Table 3). Such a large surface area of the lake particularly results from simplified methods of field measurements, and no attention paid at the time to accurate registration of inaccessible areas (wetlands). The surface area of the lake four times larger than its average range can also be attributed to high water resources registered in the catchment at the time. A similar hydrological situation was observed during research in the years 2009-2011.

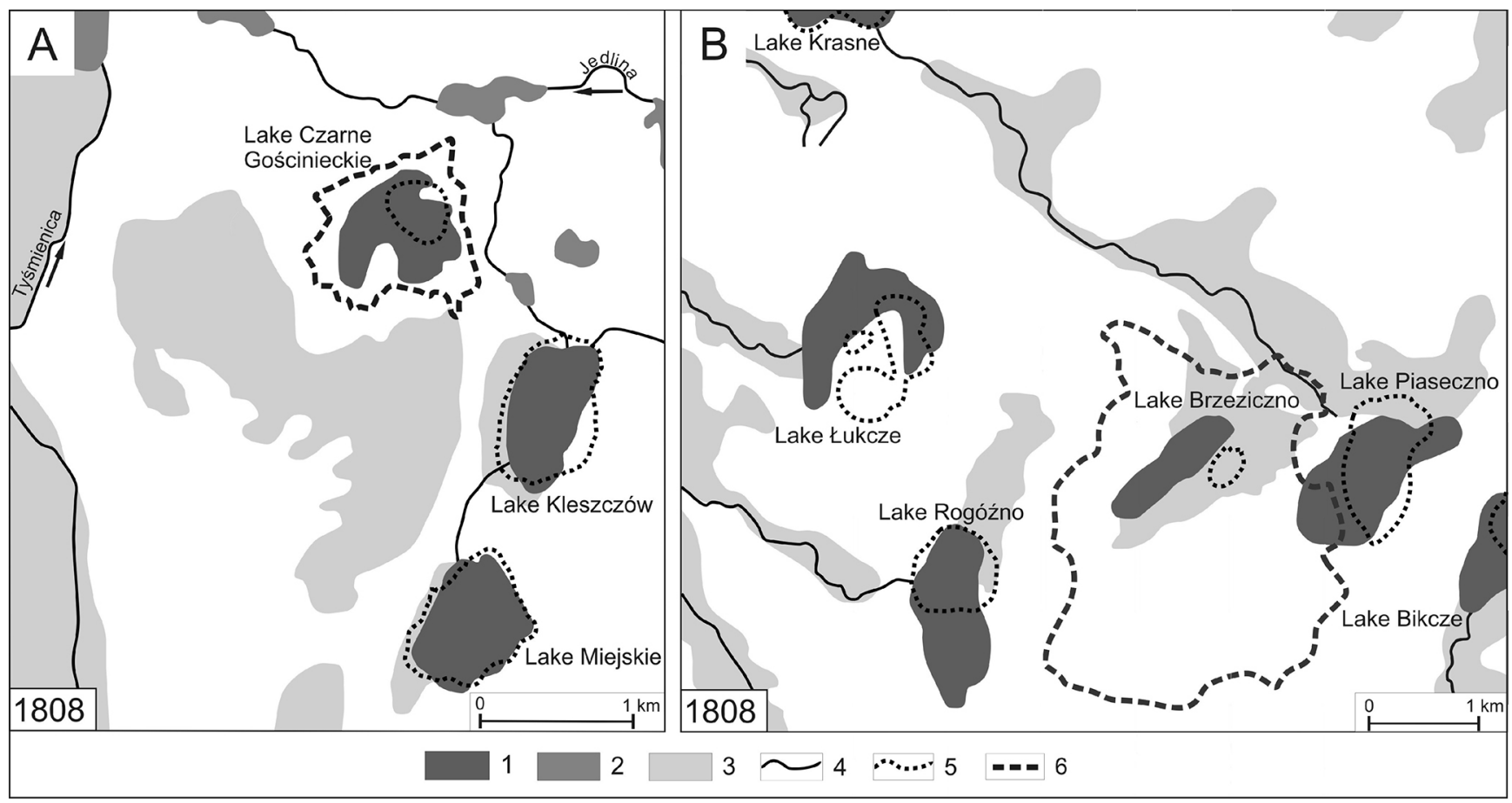

Fig. 2. Forms of water retention in the catchment of Lake Czarne Gościnieckie (A) and Lake Brzeziczno (B) and their vicinity in 1808 based on Carte von West-Gallizien 1:172 800 (Heldensfeld 1808). Explanation: 1 - natural surface retention, 2 - anthropogenic surface retention, 3 - transitional retention, 4 - streams and ditches, 5 - modern shoreline of the lakes, 6 - topographic drainage divide 
Table 3. Surface areas of particular water retention types in the catchmentof Lake Czarne Gościnieckie in 1808-2006 according to analysed historical cartographical materials (Table 2)

\begin{tabular}{|c|c|c|c|c|c|c|c|c|c|}
\hline \multirow{3}{*}{ Year } & \multicolumn{6}{|c|}{ Surface retention } & \multicolumn{2}{|c|}{ Transitional retention } & \multirow{3}{*}{ Streams, ditches [km] } \\
\hline & \multicolumn{2}{|c|}{ natural } & \multicolumn{2}{|c|}{ anthropogenic } & \multicolumn{2}{|c|}{ total } & \multirow{2}{*}[\mathrm{hm}^{2}]{} & \multirow{2}{*}[\%]{} & \\
\hline & {$\left[\mathrm{hm}^{2}\right]$} & [\%] & {$\left[\mathrm{hm}^{2}\right]$} & [\%] & {$\left[\mathrm{hm}^{2}\right]$} & {$[\%]$} & & & \\
\hline 1808 & 40.20 & 48.56 & 0 & 0 & 40.20 & 48.56 & 0.00 & 0.00 & 0.00 \\
\hline $1839-1843$ & 12.27 & 14.81 & 0 & 0 & 12.27 & 14.81 & 28.03 & 33.85 & 0.00 \\
\hline 1914 & 11.07 & 13.37 & 0 & 0 & 11.07 & 13.37 & 22.99 & 27.77 & 0.00 \\
\hline 1915 & 11.27 & 13.61 & 0 & 0 & 11.27 & 13.61 & 26.53 & 32.05 & 0.00 \\
\hline 1936 & 12.13 & 14.65 & 0 & 0 & 12.13 & 14.65 & 25.07 & 30.28 & 0.00 \\
\hline 1938 & 11.64 & 14.06 & 0.21 & 0.26 & 11.85 & 14.32 & 0.00 & 0.00 & 0.13 \\
\hline 1941 & 12.70 & 15.33 & 0.25 & 0.30 & 12.95 & 15.63 & 15.77 & 19.05 & 0.00 \\
\hline 1944 & 11.97 & 14.46 & 0.25 & 0.30 & 12.22 & 14.76 & 0.00 & 0.00 & 0.12 \\
\hline 1960 & 11.25 & 13.58 & 0 & 0 & 11.25 & 13.58 & 14.36 & 17.35 & 0.00 \\
\hline 1979 & 10.65 & 12.86 & 0 & 0 & 10.65 & 12.86 & $20.77-33.00$ & $17.00-27.00$ & 0.00 \\
\hline 1984 & 11.94 & 14.42 & 0.13 & 0.15 & 12.07 & 14.57 & 27.14 & 32.78 & 0.34 \\
\hline 1987 & 11.47 & 13.85 & 0 & 0 & 11.47 & 13.85 & 28.79 & 34.77 & 0.34 \\
\hline 2006 & 12.06 & 14.57 & 0 & 0 & 12.06 & 14.57 & 16.30 & 19.69 & 0.34 \\
\hline
\end{tabular}

Topograficzna karta Królestwa Polskiego from 18391943 presents the analysed catchment with surface retention occupying more than $12 \mathrm{hm}^{2}$ (a value approximate to results obtained in modern times). It is also the first map to present a cartographic visualization of the wetlands $\left(28.03 \mathrm{hm}^{2}\right)$ surrounding the discussed lake (Fig. 3, Table 3). Wetlands within the catchment also have a hydraulic connection with wetlands located south of the study area.

On maps released at the beginning of the 20th century (Karte des Westlichen Russland and Spezialkarte der österreichisch-ungarischen Monarchie) no substantial changes in area and proportion between the two analysed forms of retention were recorded in comparison to the previous century (Fig. 3, Table 3 ). The only significant difference is that on the map from 1914 transitional retention constitutes a separate area, having no connection to wetlands located in a southerly direction from the discussed catchment (Fig. 3).

The WIG map from 1936 (Szczegółowa mapa Polski) presents the area of wetlands (transitional retention) with a clearly marked boundary of their spatial range. Wetlands and the lake occupy 30.28 and $14.65 \%$ of the total area respectively, and are comparable in size to that presented on the most detailed map used in the study, which was released at a scale of 1:10 000 in 1984 (Table 3). In turn, on the second WIG map from 1938 (Taktyczna mapa Polski) (Fig. 3, Table 2), surface retention additionally creates a small water body (anthropogenic surface retention) probably constituting a quagmire or peat-pit pond connected with the lake through a short ditch (anthropogenic surface retention). The map shows no wetlands, but only meadows. In comparison to the image from 1915, the areas directly surrounding Lake Czarne Gościnieckie catchment show a considerable reduction of wetland areas, and an increase in the number of artificial water bodies in the Tyśmienica and Piwonia River valleys (Piwonia is also called Bobrówka or Jedlanka).

The map of the General Staff of the Red Army from 1941 presents the lake catchment with objects of natural surface retention which occupy about $15.3 \%$, and with objects of transitional retention dealing with $19 \%$ of the total catchment area (Fig. 3, Table 3). The proportions between particular forms of water retention on the US Army Map Service (1944) are almost identical as those on the WIG map released in 1938, which results from the duplication of spatial information from the WIG document.

In the next cartographic document, which is Mapa obrębowa powiatów from 1960, surface retention is only represented by a lake occupying $13.6 \%$ of the lake catchment. Transitional retention (17.4\%) was marked as wetlands directly adjacent to the lake and as two small separate areas in the southern part of the catchment.

The first thematic map used for tracing changes in forms of retention was the Szczegółowa mapa geologiczna Polski from 1979. On this map transitional retention areas in the catchment should be associated with areas covered by poor fens $(17.4 \%$ of the total area of the discussed object). The issue of assigning aggradate peats to the respective form of water retention remains debatable. Information on the peat deposits included in explanations to this map (Stochlak 1981b) make it impossible to directly qualify them, because the geological classification includes organic soils as well as loamy, silty, and sandy aggradate muds. The main criterion permitting their potential qualification as objects of transitional water retention should be percentage of contribution of organic matter. Thus, in such areas additional field hydrogeological surveys should be performed. According to the geological survey by Stochlak 


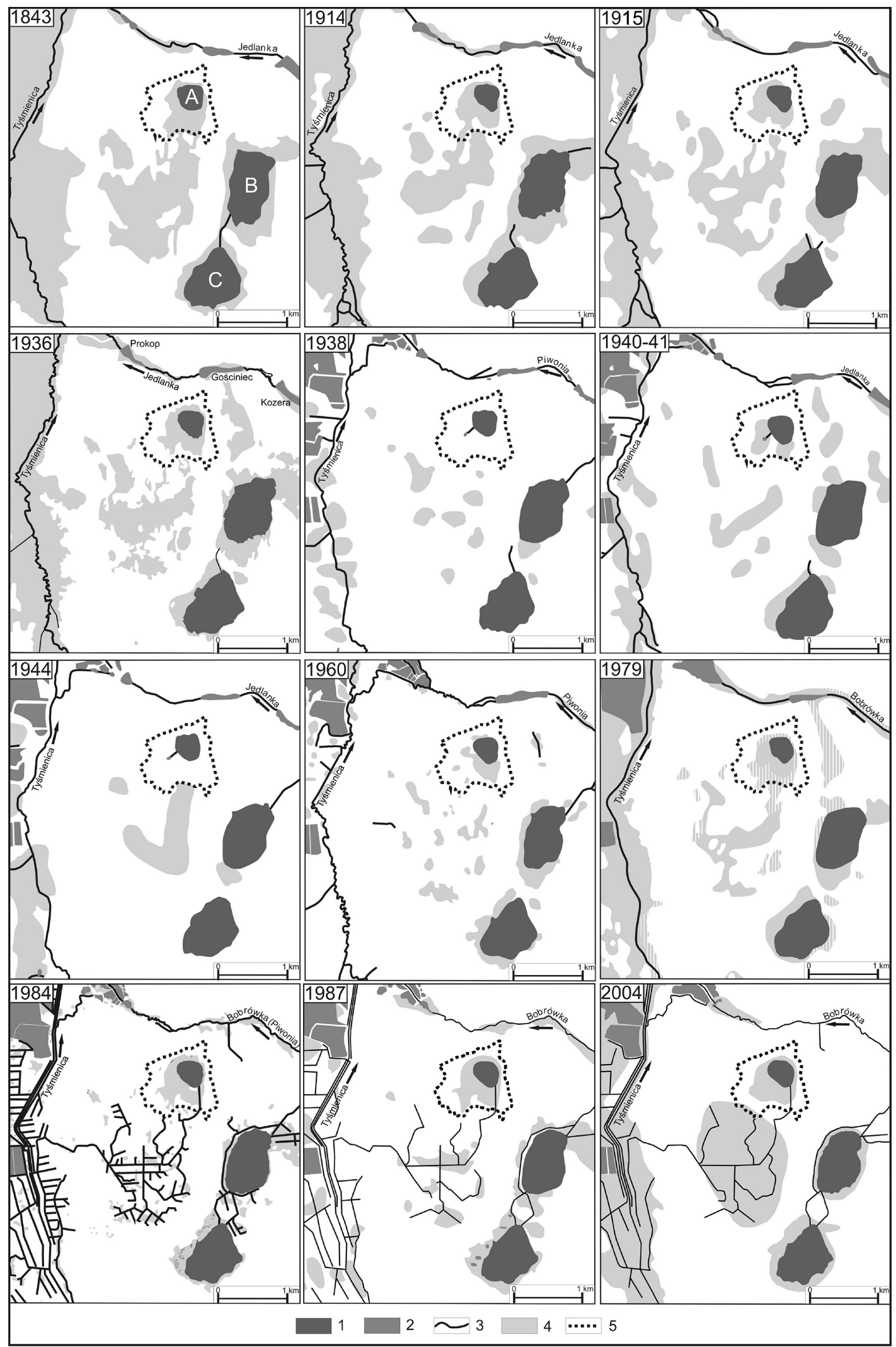

Fig. 3. Forms of water retention in the catchment of Lake Czarne Gościnieckie and its vicinity Explanation: 1 - natural surface retention, 2 - anthropogenic surface retention, 3 - transitional retention, 4 - streams and ditches, 5 - topographic drainage divide of Lake Czarne Gościnieckie catchment, A - Lake Czarne Gościnieckie, B - Lake Kleszczów, C - Lake Miejskie. Cartographic sources according to Table 2 
(1981b), transitional retention occupies between 17 and $27 \%$ of the studied catchment, and surface retention 13\% (Fig. 3, Table 2).

Issued in the mid-eighties of the last century the large-scale Topograficzna mapa Polski documents considerable transformations of the water regime of this area, particularly due to intensification of the economy of the lakeland (among others construction of a network of melioration ditches). The catchment of Lake Czarne Gościnieckie, as a result of connecting the lake with wetlands located to the south by way of a ditch, changed its character from closed to open drainage (Fig. 3, Table 3). Surface retention occurs in one lake with an area of approximately $12 \mathrm{hm}^{2}$ and two small peat pits (with a total area of $0.13 \mathrm{hm}^{2}$ ) located in the northern part of the catchment. Objects of transitional retention occupy almost one third of the study area.

Wojskowa mapa topograficzna at a scale of 1:50 000 stands out among the analysed collection of mediumscale maps by a clearly marked boundary of wetlands facilitating cartometric measurements. The total area of transitional retention on this map is $28.79 \mathrm{hm}^{2}$ and occupies $34.77 \%$ of the catchment area. Because both topographic maps from the 1980's (1:10 000 and 1:50 000) show a ditch that crosscuts the topographic drainage divide in the southern part of the study area, the catchment is assumed to have lost its closed-drainage character probably at the turn of the 1970's and 1980's.

The next example of a thematic map used in this research was the Mapa hydrograficzna Polski (1:50 000) dating from the beginning of this century (Fig. 3, Table 3 ). The cartographic analysis of wetland areas presented on this map enforces the explanation of the relatively small area of wetlands $\left(16.3 \mathrm{hm}^{2}\right)$ in comparison to those marked on the majority of maps released earlier.
Because chronologically it was the last issued cartographic document used for the research, a conclusion can be drawn concerning substantial modern drying of the catchment of Lake Czarne Gościnieckie. Such a small area of wetlands was determined according to the range of hatching (topographic symbol for wetland) a procedure usually applied to designate the range of transitional retention on all topographic maps. In the case of the hydrographic map analysis, the range of wetlands could be additionally verified by delimitation of a soil class of variable permeability (peat), or alternatively, a range of overflow areas. In the case of the latter verification criterion, the area of transitional retention in the catchment of Lake Czarne Gościnieckie would amount to $25.66 \mathrm{hm}^{2}$ - a value approximate to those determined on topographic maps.

\section{Changes in areas of retention forms in Lake Brzeziczno catchment}

Changes of the areas occupied by different forms of water retention in the catchment of Lake Brzeziczno and its vicinity over the last two centuries were traced based on the same cartographic materials as used for the analysis of the Lake Czarne Gościnieckie catchment.

Carte von West-Gallizien dated to the beginning of the 19th century is the first available cartographic document, but it features substantial distortions in terms of surface areas, angles, and distances, making it impossible to accurately analyse the study area. Particularly large deformations concern the surface areas and shorelines of lakes (Fig. 2B, Table 4) - the water bodies actually have an entirely different shape (e.g. Lake Łukcze), and are several times smaller (e.g. Lake Brzeziczno and Lake Rogóźno).

Table 4. Surface areas of particular water retention types in the catchment of Lake Brzeziczno in 1808-2006 according to analysed historical cartographical materials (Table 2)

\begin{tabular}{|c|c|c|c|c|c|c|c|c|c|}
\hline \multirow{3}{*}{ Year } & \multicolumn{6}{|c|}{ Surface retention } & \multicolumn{2}{|c|}{ Transitional retention } & \multirow{3}{*}{ Streams, ditches $[\mathrm{km}]$} \\
\hline & \multicolumn{2}{|c|}{ natural } & \multicolumn{2}{|c|}{ anthropogenic } & \multicolumn{2}{|c|}{ total } & \multirow{2}{*}[\mathrm{hm}^{2}]{} & \multirow{2}{*}{ [\%] } & \\
\hline & {$\left[\mathrm{hm}^{2}\right]$} & [\%] & {$\left[\mathrm{hm}^{2}\right]$} & [\%] & {$\left[\mathrm{hm}^{2}\right]$} & {$[\%]$} & & & \\
\hline 1808 & - & - & - & - & - & - & - & - & - \\
\hline $1839-1843$ & 7.95 & 1.13 & 0 & 0 & 7.95 & 1.13 & 169.85 & 24.04 & 0.00 \\
\hline 1914 & 8.72 & 1.23 & 0 & 0 & 8.72 & 1.23 & 92.71 & 13.12 & 2.71 \\
\hline 1915 & 7.51 & 1.06 & 0 & 0 & 7.51 & 1.06 & 88.31 & 12.50 & 3.30 \\
\hline 1936 & 9.08 & 1.28 & 0 & 0 & 9.08 & 1.28 & 88.39 & 12.51 & 2.74 \\
\hline 1938 & 6.80 & 0.96 & 0 & 0 & 6.80 & 0.96 & 44.99 & 6.37 & 5.23 \\
\hline 1941 & 7.93 & 1.12 & 0 & 0 & 7.93 & 1.12 & 53.55 & 7.58 & 3.30 \\
\hline 1944 & 6.92 & 0.98 & 0.34 & 0.05 & 7.26 & 1.03 & 63.47 & 8.98 & 6.25 \\
\hline 1960 & 7.65 & 1.08 & 0.09 & 0.01 & 7.74 & 1.09 & 0.00 & 0.00 & 0.00 \\
\hline 1981 & 7.09 & 1.00 & 0 & 0 & 7.09 & 1.00 & $13.00-67.00$ & $1.84-9.48$ & 5.21 \\
\hline 1984 & 7.91 & 1.12 & 0.01 & 0.00 & 7.92 & 1.12 & 70.71 & 10.01 & 2.28 \\
\hline 1987 & 8.07 & 1.14 & 0 & 0 & 8.07 & 1.14 & 70.49 & 9.98 & 3.69 \\
\hline 2006 & 7.06 & 1.00 & 0 & 0 & 7.06 & 1.00 & 33.95 & 4.81 & 4.12 \\
\hline
\end{tabular}




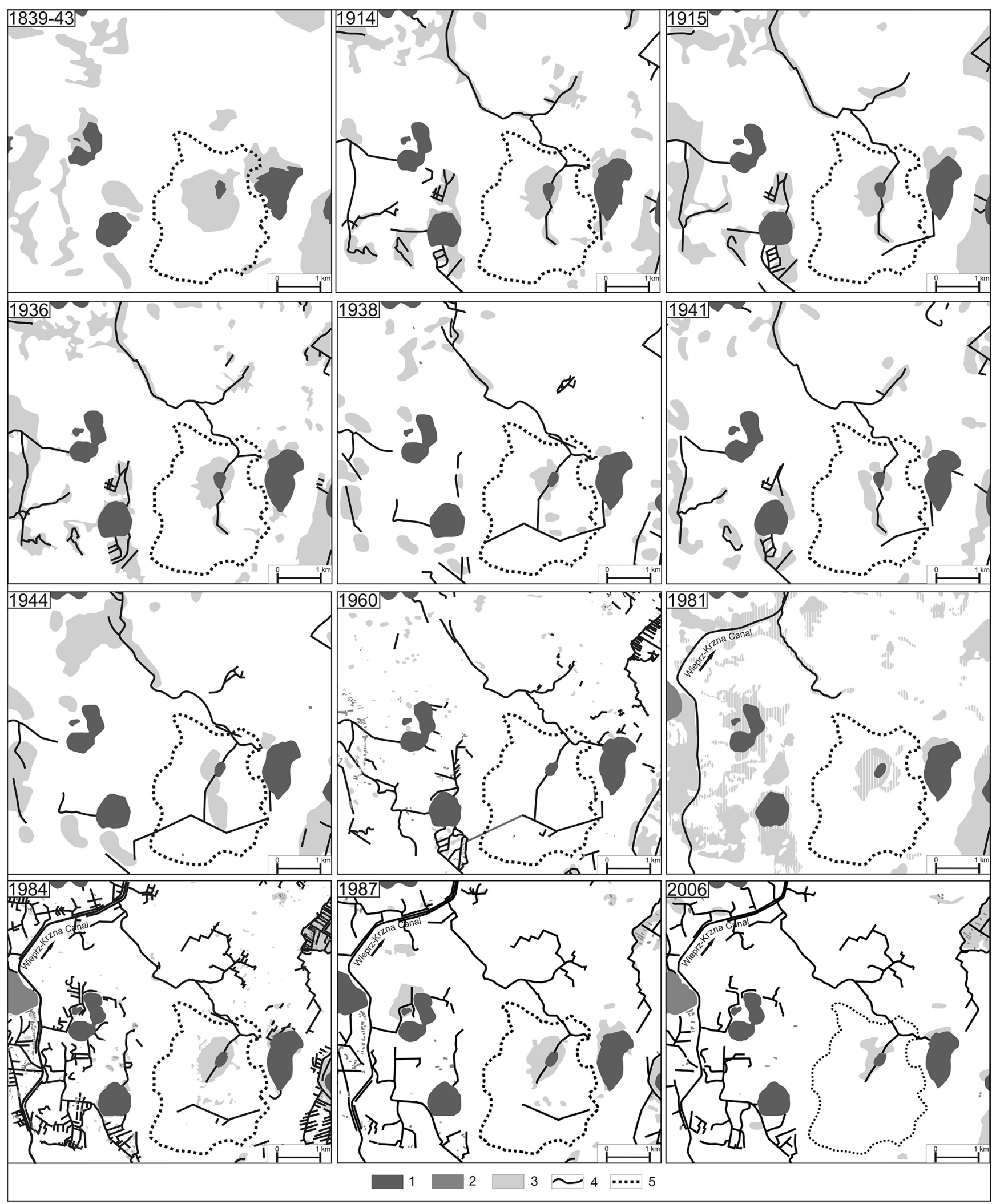

Fig. 4. Forms of retention in the catchment of Lake Brzeziczno and its vicinity. Explanation: 1 - natural surface retention, 2 - anthropogenic surface retention, 3 - transitional retention, 4 - streams and ditches, 5 - topographic drainage divide of Lake Brzeziczno catchment. Cartographic sources according to Table 2 
On Topograficzna karta Królestwa Polskiego dating from 1839-1843, the lake accounting to surface retention occupies a similar space $\left(7.95 \mathrm{hm}^{2}\right)$ to the presentday lake, although it has a different shape and course of shoreline (Fig. 4, Table 4). It is a closed-drainage lake surrounded with wetlands on all sides. Small areas of transitional retention are also located in the eastern and southern drainage divide zone. In total, areas of the type occupy approximately $170 \mathrm{hm}^{2}$ - the largest area among all the analysed maps. Lack of streams also attracts attention, although they were documented on the map from 1808.

Karte des Westlichen Russland issued in 1914 is a document showing the largest range of surface retention $\left(8.72 \mathrm{hm}^{2}\right)$ (Fig. 4, Table 4). Transitional retention is represented by two areas $\left(92.71 \mathrm{hm}^{2}\right.$ in total), namely a peatland surrounding the lake, and wetlands in the south-eastern part of the catchment.

Another document - Spezialkarte der österreichisch-ungarischen Monarchie from 1915 presents distinct changes in the hydrographic system of the study area (Fig. 4, Table 4). Due to the lack of earlier information, however, it is impossible to determine the accurate term of transformations of water circulation. It can be assumed that more or less in the mid-19th century, the catchment changed its character from closed to open drainage. The marked melioration ditches were probably dug for the purpose of draining excessively waterlogged areas. The task of the canals situated in the southern part of the catchment was drainage of excess water to Lakes Brzeziczno and Piaseczno. The melioration ditch dug in the northern fragment of the discussed area permitted control of the water level in the lake, and directing it north-west towards Lake Krasne. Surface retention, represented already by the flow-through lake on the map, occupies an area of approximately $7.5 \mathrm{hm}^{2}$. Wetlands develop a compact complex (approximately $88 \mathrm{hm}^{2}$ ) directly adjacent to the discussed lake.

In the analysis of the inter-war period (1918-1939) two maps released by WIG at different scales were used for carthometric measurements. According to measurements performed on Szczegółowa mapa Polski (1:25 000) from 1936, surface retention at this time was represented only by the lake, and reached the largest size from all analysed periods $-9.08 \mathrm{hm}^{2}$, occupying $1.28 \%$ of the catchment area. Wetlands with a total area of $88.38 \mathrm{hm}^{2}$ (12.51\%) occurred in two complexes. A large complex directly surrounding the lake, and a small one located in a forest and functioning until present-day. The ditch draining the southern part of the wetland dissected its eastern part. The second of the WIG maps (Mapa taktyczna Polski) from 1938 at a scale of 1:100 000 shows the lake having the small- est surface area $\left(6.80 \mathrm{hm}^{2}\right)$ documented in all analysed cartographic sources (Fig. 4, Table 4). Wetland areas occupy only $50 \mathrm{hm}^{2}$, whereas the peatland surrounding the lake is approximately $40 \%$ smaller than registered in 1914 and 1936. In the southern part of the catchment, on the boundary of forest and arable land, a temporarily functioning melioration ditch was dug. In the case of high water levels, excess water was drained to Lake Piaseczno.

In comparison to the WIG map from 1938, maps from the 1940s show a slightly changed hydrographic network in the Lake Brzeziczno catchment. On the Topograficheskaia karta RKKA dating from 1941, surface and transitional retention areas are inconsiderably higher in comparison to the WIG map by about $0.01 \%$ and $0.12 \%$, respectively. On the AMS Map of Poland (1944), in addition to the lake $\left(6.92 \mathrm{hm}^{2}\right)$, surface retention is also represented by a small pond $\left(0.34 \mathrm{hm}^{2}\right)$ located in Uciekajka village. Wetlands are only located on the western side of the lake, and develop a compact elongated complex $\left(63.47 \mathrm{hm}^{2}\right)$ hydrologically bonded with a periodically functioning channel (melioration ditch) (Fig. 4, Table 4).

Another document, Mapa obrębowa powiatów (1960), shows no objects of transitional retention in the area of the studied catchment (Fig. 4, Table 4). Surface retention is represented by the lake $\left(7.65 \mathrm{hm}^{2}\right)$ and two small ponds in Uciekajka village.

On the Szczegółowa mapa geologiczna Polski from 1981, Lake Brzeziczno occupies an area of $7.91 \mathrm{hm}^{2}$ (Fig. 4, Table 4). Transitional retention is represented by low peatlands adjacent to the lake to the east. Areas developed by aggradate peats, like in the case of the Lake Czarne Gościnieckie catchment, should be potentially qualified as transitional retention based on additional hydrogeological research. Due to this, depending on the adopted delimitation criterion, transitional retention can occupy an area from approximately 13 to $67 \mathrm{hm}^{2}$.

Topograficzna mapa Polski (1:10 000) issued in 1984 is the most detailed topographic document ever prepared for this area. It documents the existence of the lake $\left(7.09 \mathrm{hm}^{2}\right)$ and one pond $\left(0.01 \mathrm{hm}^{2}\right)$ located in the southern fragment of the studied catchment. Transitional retention is represented mainly by a peatland surrounding the lake, and approximately a dozen other wetlands (with a total area of $70.71 \mathrm{hm}^{2}$ ), mainly located in the central part of the discussed area (Fig. 4, Table 4). Also, measurements carried out on the Wojskowa mapa topograficzna (1: 50 000) released in 1987 provided similar results. Differences in the surface area occupied by different forms of retention result from the generalisation of the medium-scale map (Table 4). 


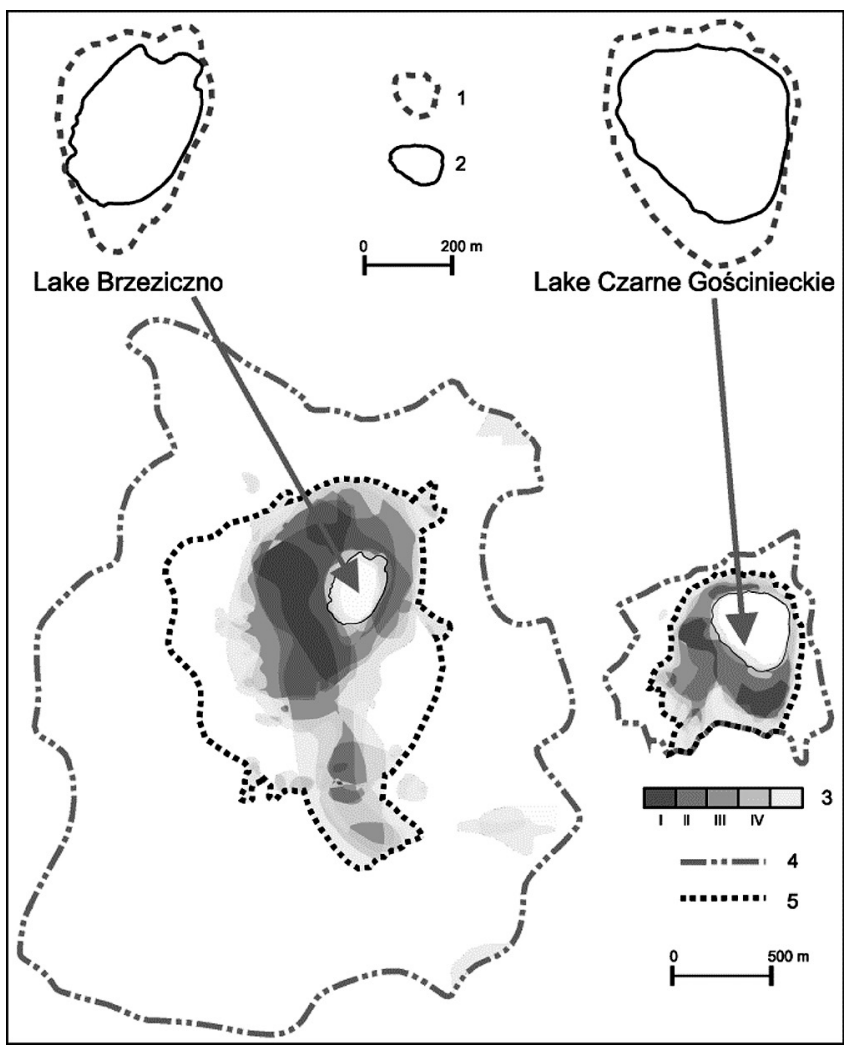

Fig. 5. Effect of overlapping of ranges of retention forms from the analysed maps. Explanation: 1 - maximum range of the lake presented on maps, 2 - shoreline of the modern lake (2015), 3 - transitional retention areas, 4 - topographic drainage divide, 5 - maximum range of the transitional retention zone marked on maps

Hydrographic content of the second thematic map used for research of the Lake Brzeziczno catchment (Mapa hydrograficzna Polski) from 2006 are characterised by the inaccuracy of the graphic presentation of wetland area boundaries. They were marked on the map with hatching only but their borders were not specified. Similarly to the case of analysis of wetlands in the Lake Czarne Gościnieckie catchment, this results in determination of their considerably smaller surface area than on topographic maps. In the case of the Brzeziczno catchment, the verification of the range of wetlands could be performed by means of determination of boundaries of the variable class of soil permeability, including peatlands. It should be remembered that considerable areas of peatlands of West Polesie have dried out, and they are not wetlands anymore from the hydrological point of view.

An important issue in the analysis of transformations of water-swamp ecosystems of small lake catchments is the attempt to estimate changes also occurring in their immediate vicinity. Juxtaposition of the hydrographic content of the two most detailed documents used in the study, comparable in scale (1:25 000) and elaborated both before the melioration works related to the construction of the Wieprz-Krzna Canal system (Szczegółowa mapa Polski), and 20 years after its launch (Topograficzna mapa Polski) reveals a stable range of the areas occupied by transitional and surface retention in the studied catchments. This picture is in evident opposition to that observed in ambient areas, where an clearly visible reduction of the area of wetlands has occurred (Figs 3 and 4).

For the purpose of determining the areas with the lowest dynamics of lake and wetland area changes, layers of hydrographic information placed on particular maps were imposed on each other. Areas of transitional retention marked most frequently were divided into four classes. Grayscale intensity indicates the repeatability of the range of areas of transitional retention on consecutive maps (Fig. 5). These designations can be considered as the most durable spaces of wetlands over the last two centuries. The image approximately corresponds with the situations of modern water distribution in the zones surrounding the discussed lakes.

The review of cartographic documents from the last two centuries used for the study shows their scarcity in comparison to the archival material of north Poland (Barbach 2012). The practice of copying map contents commonly applied by the occupants, and lack of documents determining of the period of performance of the field inventory for the borderland area, i.e. West Polesie, makes it difficult, or even impossible to accurately date the topographic situation, therefore renders them often useless.

The period 1926-1960 and the turn of the 20th and 21 st century were the richest in the number of archival maps with contents subject to analysis (Fig. 6). The analysis of changes in surface areas occupied by objects of surface and transitional retention determined in all the studied maps is not sufficient for drawing a conclusion on their substantial reduction. Trends presented in Figure 6 (A1, B1) show a small decline in the surface area of water bodies, and in the case of wetlands (transitional retention), the directions of changes in the catchments of Lakes Czarne Gościnieckie and Brzeziczno are opposite (Fig. 6 A2, B2). A particularly large area of a wetland surrounding Lake Brzeziczno was marked on the Topographic Map of the Polish Kingdom from 1839-1843 (Fig. 6 B2). This effect was undoubtedly largely determined by application in the study of maps made at different scales, and therefore generalisation of the designation of wetlands, and negligence of measurements of inaccessible areas in earlier surveys. 

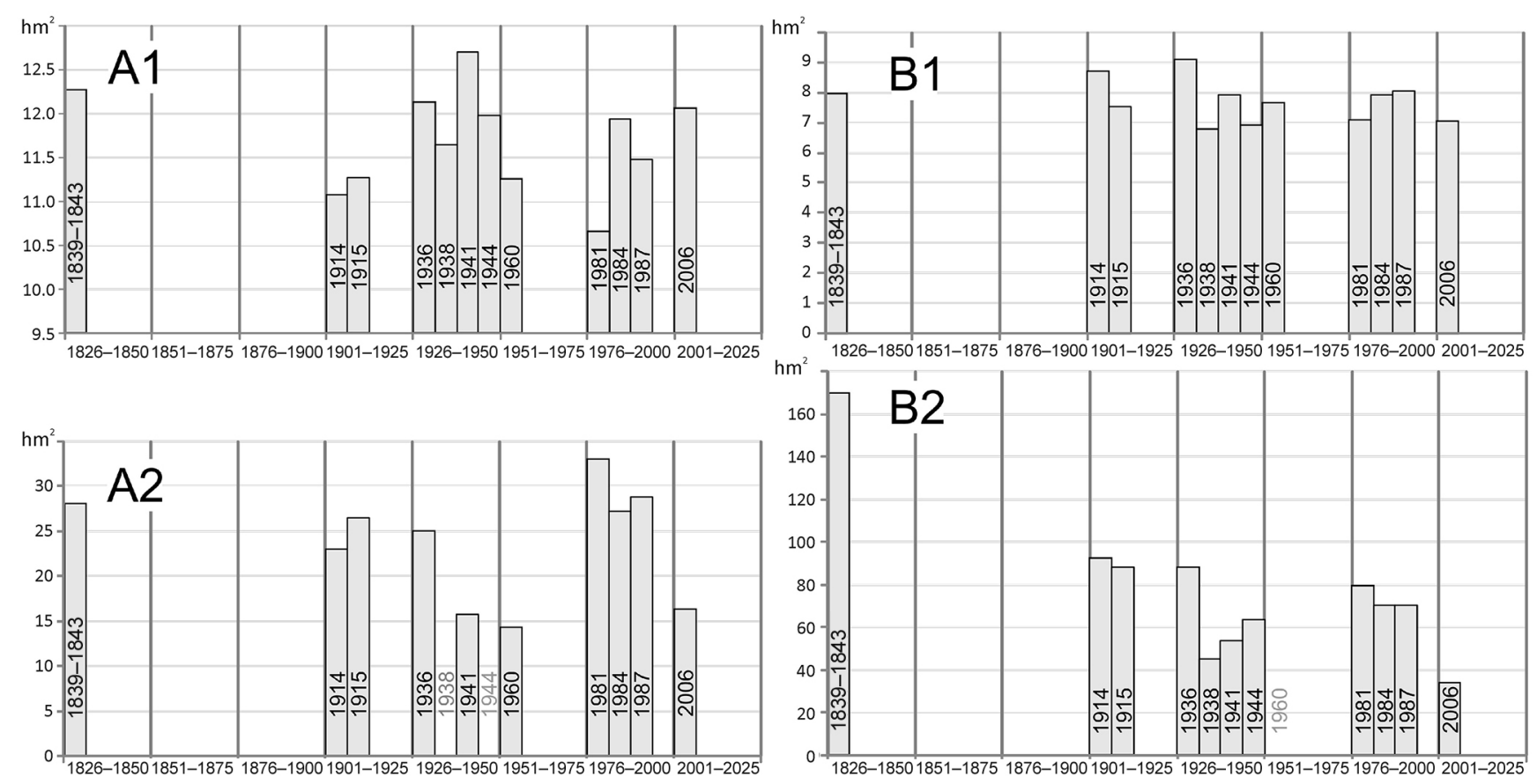

Fig. 6. Changes in the area of surface and transitional retention types in analysed lake catchments in consecutive 25-year periods. Explanation: A - surface retention (A1) and transitional retention (A2) in the Lake Czarne Gościnieckie catchment, B - surface retention (B1) and transitional retention (B2) in the Lake Brzeziczno catchment

\section{Conclusion}

Melioration works applied on the extensive wetlands of Polesie contributed to irreversible changes of its ecosystems. Nonetheless, wetland areas with a quasi-natural character were retained over small areas. Several of them were incorporated into larger complexes of protected areas such as national parks. Outside the boundaries of the Polesie National Park, two small lake-peatland catchments in the western part of the Łęczna-Włodawa Lakeland deserve particular attention, namely catchments of Lakes Czarne Gościnieckie and Brzeziczno. They are specific due to the preservation of considerable (in comparison to the size of the catchment) areas of transitional retention (wetlands) around small lakes in the last phase of evolution.

In spite of considerable difficulties with the verification of the content of historical maps, such as copying content from older maps or their incomplete cartometric character, they are a very valuable source of data, considerably extending the analysis period. They are the only material providing the basis for measurements of distance and surface area of the studied spatial objects. Among the analyzed historical maps, the most valuable are the Taktyczna mapa Polski (1:100 000) issued before World War II and the least useful for geohistorical research is characterized by the oldest maps and the twentieth-century Mapa obrębowa powiatów
(1:25 000) from 1960. This assessment is consistent with the analysis of the quality of historical maps conducted by Nita and Myga-Piątek (2012).

The cartographic analyses and text documents describing the procedures of their preparation and including numerical data concerning the areas of two small, weakly managed lake catchments of West Polesie suggest that in the period from the beginning of the $19^{\text {th }}$ century, no substantial changes occurred in the surface area of the analysed forms of water retention. Areas occupied by the lakes (surface retention) retain relative stability, with their simultaneous shallowing. The areas of transitional retention (wetlands), the most difficult to designate on maps, are characterised by almost natural conditions of accumulation of water resources due to a small (in comparison to the entire region of Polesie) degree of drainage.

The analysis of changes in the aquatic conditions based on historical maps can help the selection of appropriate hydrogenic areas for protection, and provides the basis for the determination of approaches to their management.

\section{Acknowledgments}

This study was partly supported from the funds of Polish Ministry of Sciences and High Education in the framework of grant No. 1803/B/PO1/2009/37: Importance of transitional retention zones in water inflow to lakes. 


\section{References}

[AMS] US Army Map Service, 1944, AMS M651 (GSGS 4416) Map of Poland. Sheet Q-17 Lubartow, US Army Army Map Service, Washington. Retrieved from http:// igrek.amzp.pl/mapindex.php?cat=ALLIED100CE [accessed 20 October 2017].

Affek A., 2013, Georeferencing of historical maps using GIS: As exemplified by the Austrian military surveys of Galicia, Geogr. Polon. 86(4): 375-390.

Barabach J., 2012, The history of Lake Rzecin and its surroundings drawn on maps as a background to palaeoecological reconstruction, Limnol. Rev. 12(3): 103-114.

Borowiec J., 1990, Torfowiska regionu lubelskiego (Peatlands of the Lublin region), Wydaw. Nauk. PWN, Warszawa, 348 pp (in Polish).

Brooks R.T., 2004, Weather-related effects on woodland vernal pool hydrology and hydroperiod, Wetlands 24(1): 104-114.

Brooks R.T., 2005, A review of basin morphology and pool hydrology of isolated ponded wetlands: implications for seasonal forest pools of the northeastern United States, Wetland Ecol. Manage. 13(3): 335-348.

Brooks R.T., Hayashi M., 2002, Depth-area-volume and hydroperiod relationships of ephemeral (vernal) forest pools in southern New England, Wetlands 22(2): 247-255.

Buczek K., 1963, Dzieje kartografii polskiej od XV do XVIII wieku. Zarys analityczno-syntetyczny (History of Polish cartography from XV to XVIII century. An analytical and synthetic outline), Zakład Narodowy im. Ossolińskich, Wrocław, 119 pp (in Polish).

Buraczyński J., Wojtanowicz J., 1981a, Szczegółowa mapa geologiczna Polski 1:50 000. Arkusz Orzechów Nowy 715 (Detailed geological map of Poland 1: 50 000. Sheet Orzechów Nowy 715), Wydaw. Geol., Warszawa.

Buraczyński J., Wojtanowicz J., 1981b, Objaśnienia do szczegółowej mapy geologicznej Polski 1:50 000. Arkusz Orzechów Nowy 715 (Explanations to the detailed geological map of Poland 1:50 000. Sheet Orzechów Nowy 715), Wydaw. Geol., Warszawa, 87 pp (in Polish).

Cebrykow P., 2015, Dawne mapy topograficzne Lubelszczyzny jako źródła informacji w badaniach historyczno-geograficznych (Old topographical maps of the Lublin region as sources of information in historical and geographic research), [in:] Czerny A. (ed.), Dawne mapy topograficzne w badaniach geograficzno-historycznych (Old topographic maps in geographical and historical studies), Wydaw. UMCS, Lublin: 85-102 (in Polish).

Chmielewski T.J., Radawan S., 1996, Procesy ekologiczne zachodzące w płytkich jeziorach i otaczających je torfowiskach na Pojezierzu Łęczyńsko-Włodawskim (Ecological processes taking place in shallow lakes and peatlands surrounding them in the Łęczna-Włodawa Lake District), [in:] Radwan S. (ed.), Fukcjonowanie ekosystemów wodno-błotnych w obszarach chronionych Polesia (Function- ing of wetland ecosystems in protected areas of Polesie), Wydaw. UMCS, Lublin: 31-43 (in Polish).

Choiński A., 2007, Limnologia fizyczna Polski (Physical limnology of Poland), Wydaw. Nauk. UAM, Poznań, 548 pp (in Polish).

Churski Z., 1988, Wpływ gospodarczej działalności człowieka na zmiany jezior i mokradeł na Pojezierzu Brodnickim (Economic impact of human activities on changes of lakes and wetlands in the Brodnica Lake District), [in:] Churski Z. (ed.), Naturalne i antropogeniczne przemiany jezior i mokradeł w Polsce (Natural and anthropogenic changes of lakes and wetlands in Poland), Wydaw. UMK, Toruń: 182-194 (in Polish).

Churski Z., 1993, Antropogeniczne i naturalne tendencje rozwoju jezior i mokradeł (Anthropogenic and natural tendencies of lakes and wetlands evolution), [in:] Dynowska I. (ed.), Przemiany stosunków wodnych w Polsce w wyniku procesów naturalnych i antropogenicznych (Transformation of water conditions in Poland as a result of natural and anthropogenic processes), Wydaw. UJ, Kraków: 53-210 (in Polish).

Czaja K., Jańczak J., 2010, Zanikanie jezior w dorzeczu Raduni w ostatnim stuleciu (Lakes disappearance in Radunia River basin over the last century), [in:] Choiński A. (ed.), Przemiany jezior i zbiornikow wodnych (Transformations of lakes and reservoirs), Bogucki Wydaw. Nauk., Poznań: 55-67 (in Polish, English summary).

Czerny A., 2015, Powstanie i etapy rozwoju map topograficznych do końca XIX wieku (Making and stages of development of topographic maps by the end of the 19th century), [in:] Czerny A. (ed.), Dawne mapy topograficzne w badaniach geograficzno-historycznych (Old topographic maps in geographical and historical studies), Wydaw. UMCS, Lublin: 11-83 (in Polish).

Dembek W., Pawlaczyk P., Sienkiewicz J., Dzierża P., 2004, Obszary wodno-błotne w Polsce (Wetlands in Poland), Wydaw. IMUZ, Falenty, 76 pp (in Polish).

Dębski K., 1970, Hydrologia (Hydrology), Wydaw. Arkady, Warszawa, 367 pp (in Polish).

Fabich, A., Kwidzińska M., 2012, Changes in the water surface area of Lakes Udzierz and Mątasek in the light of cartographic materials, Limnol. Rev. 12(4): 169-177.

Gałka M., 2007, Geograficzno-historyczne studium mokradeł południowo-wschodniej części ziemi świeckiej (Geographical and historical study of the wetlands of the south-eastern part of the Świecie region), Pr. Zakładu Biogeografii i Paleoekologii UAM w Poznaniu. Tom 7, Wydaw. Nauk. Bogucki, Poznań, 98 pp (in Polish, English summary).

Gałka M., 2007, Zmiany jeziorno-torfowiskowe w ujściowym odcinku Strugi Siedmiu Jezior (Lake-peat changes in the mouth of Seven Lakes River), Pr. Zakładu Biogeografii i Paleoekologii UAM w Poznaniu. Tom 8, Wydaw. Nauk. Bogucki, Poznań, 76 pp (in Polish English summary).

[Genshtab RKKA] General'nyi shtab Raboche-Krest'yanskoi Krasnoi Armii (General Staff of the Red Army), 1941, 
Topograficheskaia karta RKKA 1:50 000. List: M-34-22-B Parchev, M-34-23-B Ozhekhuv Novy, M-34-22-G Ostruv Liubel'ski, M-34-22-V Liubartuv, M-34-23-B Kaplonosy (Topographic map of the PKKA. Sheet: M-34-22-B Parchev, M-34-23-B Ozhekhuv Novy, M-34-22-G Ostruv Liubel'ski, M-34-22-V Liubartuv, M-34-23-B Kaplonosy), General'nyi shtab RKKA. Retrived from http:// igrek.amzp.pl/mapindex.php?cat=USSR050 [accessed 20 October 2017].

Graf R., Kaniecki A., Medyńska-Gulij B., 2008, Dawne mapy jako źródło informacji o wodach śródlądowych i stopniu ich antropogenicznych przeobrażeń (Old maps as a source of information about inland waters and the extent of their man-made transformations), Bad. Fizjogr. Pol. Zach., A 59: 11-28 (in Polish, English summary).

[GUGiK] Główny Urząd Geodezji i Kartografii (Head Office of Geodesy and Cartography), 1984a, Topograficzna mapa Polski 1:10 000. Arkusz: Ostrów Lubelski 126.342, Kaniwola 136.342 (Topographic Map of Poland 1:10 000. Sheet: Ostrów Lubelski 126.342, Kaniwola 136.342).

[GUGiK] Główny Urząd Geodezji i Kartografii (Head Office of Geodesy and Cartography), 2006, Mapa hydrograficzna Polski 1:50 000. Arkusz: M-34-34-B Urszulin, M-34-22-B Parczew (Hydrographic map of Poland 1:50 000. Sheet: M-34-34-B Urszulin, M-34-22-B Parczew), Warszawa.

[GUGiK] Główny Urząd Geodezji i Kartografii (Head Office of Geodesy and Cartography), 2017, Geoportal krajowy (National Geoportal). Available at http://www.geoportal. gov.pl/ [accessed 20 October 2017].

Gutry-Korycka, 1997, Formy retencji powierzchniowej (Forms of surface retention), [in:] Soczyńska U. (ed.), Hydrologia dynamiczna (Dynamic hydrology), Wydaw. Nauk. PWN, Warszawa: 185-230 (in Polish).

Heldensfeld von A., 1808, Carte von West-Gallizien 1:172 800. Blatt No 6 (Map of Western Galicia 1:172 800. Sheet No 6), Generalquartiermeisterstaab, Wien. Retrieved from http://bcul.lib.uni.lodz.pl/dlibra/docmetadata?id=1 269\&from=publication [accessed 20 October 2017].

Hilbricht-Ilkowska A., 1993, Temperate freshwater ecotones: problem with seasonal instability, [in:] Gopal B., Hillbricht-Ilkowska A., Wetzel R. G. (eds.), Wetland and ecotones. Studies on land-water interactions, National Institute of Ecology, New Delhi: 17-34.

Ilnicki P., 2002, Torfowiska i torf (Peatlands and peat), Wydaw. AR, Poznań: 606 pp (in Polish).

Jop S., 1998, Zasiedlenie Pojezierza w rejonie Ostrowa Lubelskiego XIII-XVIII w. (Settlement of the Pojezierze District near Ostrów Lubelski XIII-XVIII centuries), LTN, Lublin, 167 pp. (in Polish).

[KG WP] Kwatermistrzostwo Generalne Wojska Polskiego (General Quartermaster of the Polish Army), 1839-1843, Topograficzna karta Królestwa Polskiego 1:126 000. Arkusz Kol. VI-Sek. IX (Topographic map of the Polish Kingdom 1: 126 000. Sheet Kol. VI-Sek. IX), Peters- burg. Retrieved from http://igrek.amzp.pl/mapindex. php?cat=KWATERMISTRZ [accessed 20 October 2017].

[K.K. MGI] Kaiserlich-Königlich Militärgeographische Institut (Imperial-Royal Military Geographical Institute), 1915, Spezialkarte der österreichisch-ungarischen Monarchie 1:75 000. Blatt: A-XXVII Lublin und Lubartów, AXXVIII Łęczna, B-XXVIII Parczew (Special map of the Austro-Hungarian monarchy. Sheets: A-XXVII Lublin und Lubartów, A-XXVIII Łęczna, B-XXVIII Parczew), K.K. Generalquartiermeisterstabs, Vien. Retrieved from: http://igrek.amzp.pl/mapindex.php?cat=KUK075 [accessed 20 October 2017].

Kowalewski G., 2003, Przeobrażenia jezior i mokradeł w strefie oddziaływania Zbiornika Koronowskiego (Transformation of lakes and wetlands into the impact zone of the Koronowski Reservoir), Pr. Zakładu Biogeografii i Paleoekologii UAM. Tom 3, Bogucki Wydaw. Nauk., Poznań, 62 pp (in Polish, English summary).

Kowalewski G., 2012, Over 200 years of drainage practices and lake level drawdown in the Uścimowskie Lowering (Łęczna-Włodawa Lakeland), Limnol. Rev. 12(4): 179190.

[KPL] Königlich Preussische Landesaufnahme (Royal Prussian Land Survey), 1914, Karte des Westlichen Russlands 1:100 000. Arkusze: M-35 Parczew, M-36 Łęczna (Map of the western Russia 1:100 000. Sheets: M-35 Parczew, M-36 Łęczna), Kartographische Abteilung d. Königl. Preuss. Landesaufnahme. Retrived from http://maps. mapywig.org/m/German_maps/series/100K_KdWR/ [accessed 20 October 2017].

Kramkowski M., Bartczak A., Kaczmarek H., Słowiński M., Tyszkowski S., 2014, Naturalne i antropogeniczne uwarunkowania przestrzennych zmian obszarów wodnobłotnych na przykładzie Jeziora Rakutowskiego w świetle archiwalnych materiałów kartograficznych i fotogrametrycznych (Natural and anthropogenic conditions of spatial changes of wetlands on the example of Rakutowski Lake in the light of archival cartographic and photogrammetric materials), Prob. Ekol. Kraj. 37: 169-179.

Krassowski B., 1974, Polska kartografia wojskowa w latach 1918-1945 (Polish military cartography in the years 1918-1945), Wydaw. MON, Warszawa, 362 pp (in Polish).

Krassowski B., 1978, Topograficzna karta Królestwa Polskiego: 1822-1843 (Topographic map of the Polish Kingdom: 1822-1843), BN. Zakł. Zb. Kartogr., Warszawa, 36 pp (in Polish, English and Russian summary).

Kuna J., 2015, Metodyczne aspekty analiz przestrzennych GIS wykorzystujących dawne mapy topograficzne (Methodical aspects of GIS spatial analysis using old topographic maps) [in:] Czerny A. (ed.), Dawne mapy topograficzne w badaniach geograficzno-historycznych (Old topographic maps in geographical and historical studies), Wydaw. UMCS, Lublin: 125-149 (in Polish).

Lamentowicz M., 2005, Geneza torfowisk naturalnych i seminaturalnych w Nadleśnictwie Tuchola (The genesis 
of natural and seminal peatlands in the Tuchola Forest District), Pr. Zakładu Biogeografii i Paleoekologii UAM. Tom 5, Bogucki Wydaw. Nauk., 102 pp. (in Polish, English summary).

Liszkowski J., 1979a, Szczegółowa mapa geologiczna Polski 1:50 000. Arkusz Ostrów Lubelski 714 (Detailed geological map of Poland 1:50 000. Sheet Ostrów Lubelski 714), Wydaw. Geol., Warszawa, 100 pp (in Polish).

Liszkowski J., 1979b, Objaśnienia do szczegółowej mapy geologicznej Polski 1:50 000. Arkusz Ostrów Lubelski 714 (Explanations to the detailed geological map of Poland 1:50 000. Sheet Ostrów Lubelski 714), Wydaw. Geol., Warszawa, 100 pp (in Polish).

Marszelewski W., 2005, Zmiany warunków abiotycznych w jeziorach Polski północno-wschodniej (Changes of abiotic conditions in the lakes of North-Eastern Poland), Wydaw. UMK, Toruń, 288 pp (in Polish, English summary).

Marszelewski W., Adamczyk A., 2004, Changes in the area of the Mazurian Lakes in the light of the cartographic materials at the scale 1:25 000, Limnol. Rev. 4: 167-176.

Marszelewski W., Ptak M., Skowron R., 2011, Antropogeniczne i naturalne uwarunkowania zaniku jezior na Pojezierzu Wielkopolsko-Kujawskim (Anthropogenic and natural conditioning of the disappearance of lakes in the Wielkopolska-Kujawskie Lake District), Rocz. Glebozn. 62(2): 283-294 (in Polish, English summary).

Michalczyk Z., Turczyński M., 1998, Przekształcenia i zagrożenia hydrosfery (Transformations and dangers of the hydrosphere), [in:] Harasimiuk M., Michalczyk Z., Turczyński M. (eds.), Jeziora łęczyńsko-włodawskie. Monografia przyrodnicza (Łęczyńsko-Włodawskie Lakes. Nature monograph), Wydaw. UMCS - PIOŚ, Lublin: 157-164 (in Polish).

Mięsiak K., Turczyński M., Szwajgier W., 2005, Environmental transformations in Lake Lejno catchment basin, Limnol. Rev. 5: 175-182.

Mięsiak-Wójcik K., Turczyński M., Sposób J., 2014, Natural and anthropogenic changes of standing water bodies in West Polesie (East Poland), Proc. of the 2nd International Conference on Water resources and wetlands, 11-13 September, Tulcea: $36-43$.

Nita J., Myga-Piątek U., 2012, Rola GIS w ocenie historycznych opracowań kartograficznych na przykładzie Wyżyny Częstochowskiej (Use of GIS in assessment of historical cartographic materials - Case study Częstochowska Upland), Pr. Kom. Kraj. Kult. PTG 16: 116-135 (in Polish, English summary).

Okruszko H., 1991, Przeobrażanie się mokradeł pod wpływem odwodnienia (Transformation of wetlands under the influence of drainage), Zesz. Probl. Post. Nauk Rol., 372: 251-269 (in Polish).

Olszewicz, B., 1921, Polska kartografja wojskowa. Zarys historyczny (Polish military cartography. Historical outline), Wojskowy Inst. Nauk.-Wydaw., Warszawa, 199 pp (in Polish, French summary).
Oprawko H., Schuster K., 1962, Lustracja województwa lubelskiego 1661 (Lustration of the Lubelskie Voivodeship 1661), PWN, Warszawa, 263 pp (in Polish).

Panecki T., 2015, Porównanie zakresu i metod ujęcia treści na mapach topograficznych ziem zaboru rosyjskiego z przełomu XIX i XX wieku (The comparison of the scope of the content and classification methods on topographical maps of Polish territory annexed by Russia issued at the turn of 19th and 20th century), Pol. Prz. Kartogr. 47(1): 47-65 (in Polish, English summary).

Piasecki A., 2013, Zmiany powierzchni jezior Pojezierza Dobrzyńskiego w świetle materiałów kartograficznych (Changes in lake surface areas in the Dobrzyń Lake District in the light of cartographic materials), Pr. Geogr. IGGP UJ 132: 39-57 (in Polish, English summary).

Pieczyńska E., 1990, Lentic aquatic-terrestrial ecotones: their structure, functions, and importance [in:] Naiman R. J., Decamps H. (eds.), The ecology and management of aquatic-terrestrial ecotones, UNESCO - Parthenon Publ., Carnforth: 103-140.

Ptak M., 2013, Historical medium-scale maps as a source of information on the overgrowing of lakes, Limnol. Rev. 13(3): 155-162.

Ralska-Jasiewiczowa M., Starkel L., 1988, Record of the hydrological changes during the Holocene in the lake, mire and fluvial deposits of Poland, Folia Quarter. 57: 91-127.

Sawicki L., 1928, Obristens Anton Freiherr Mayer von Heldensfeld topographische Aufnahme Westgalliziens in den jahren 1801-1804 (Colonel Antoni Baron Mayer von Heldensfeld topographic photographs in Poland in 1801-1804, Prace Inst. Geogr. UJ 10: 7-111 (in German).

Perthées de K., 1806, Mappa szczegulna woiewodztwa lubelskiego 1:2525 000 (Detailed map of the Lublin Voivodeship, 1:225 000), Paris. Retrived from https://fbc.pionier. net.pl/details/nnzwms6 [accessed 20 October 2017].

Starkel L., Pazdur A., Pazdur M. F., Wicik B., Więckowski K., 1996, Lake-level and groundwater-level changes in the Lake Gościąż area, Poland: palaeoclimatic implications, Holocene 6(2): 213-224.

Stochlak J., 1979a, Szczegółowa mapa geologiczna Polski 1: 50 000. Arkusz: Parczew 678 (Detailed geological map of Poland 1: 50 000. Sheet Parczew 678), Wydaw. Geol., Warszawa.

Stochlak J., 1979b, Objaśnienia do szczegółowej mapy geologicznej Polski 1: 50 000. Arkusz Parczew 678 (Explanations to the detailed geological map of Poland 1: 50000. Sheet Parczew 678), Wydaw. Geol., Warszawa, 120 pp. (in Polish).

Superson J., Szwajgier W., 2003, Natural and anthropogenic conditioning of the changes of the shoreline of Brudno, Brudziec and Płotycze lakes (the Łęczna - Włodawa Lake District), Limnol. Rev. 3: 223-229.

Szady B., 2008, Zastosowanie systemów informacji geograficznej w geografii historycznej (Application of geographic information systems in historical geography), Pol. Prz. Kartogr. 40(3): 279-283 (in Polish). 
Tobolski K., 2003, Torfowiska na przykładzie Ziemi Świeckiej (Mires on example of the Świecie region), Tow. Przyjació Dolnej Wisły, Świecie, 255 pp (in Polish).

[WIG] Wojskowy Instytut Geograficzny (Military Geographical Institute), 1936, Szczegółowa mapa Polski 1:25 000. Arkusze: P42-S36-G, P43-S36-D, P43-S36-E (Detailed map of Poland 1:25 000. Sheets: P42-S36-G, P43-S36-D, P43-S36-E), Wydz. Kartogr. WIG, Warszawa. Retrived from http://igrek.amzp.pl/mapindex.php?cat=WIG25 [accessed 20 October 2017].

[WIG] Wojskowy Instytut Geograficzny (Military Geographical Institute), 1938, Mapa taktyczna Polski 1:100 000. Arkusze: P-43 S-36 Łęczna, P-42 S-36 Parczew (Tactical Map of Poland 1:100 000. Sheets: P-43 S-36 Łęczna, P-42 S-36 Parczew), Wydz. Kartogr. WIG, Warszawa. Retrived from http://igrek.amzp.pl/mapindex.php?cat=WIG100 [accessed 20 October 2017].

Wilgat T., 1954, Jeziora Łęczyńsko-Włodawskie (ŁęcznaWłodawa lakes), Ann. UMCS B 8: 37-122 (in Polish, English summary).
Wyczański A., 1959, Lustracja województwa lubelskiego 1565 (Lustration of the Lubelskie Voivodeship 1565), Zakład Narodowy im. Ossolińskich, Wrocław, 138 pp (in Polish).

[ZTSG] Zarząd Topograficzny Sztabu Generalnego (Topographical Board of the General Staff), 1960, Mapa obrębowa powiatów 1:25 000. Powiat Lubartów. Arkusz: 6, 7, 11 (Precint map of counties 1:25 000. Lubartów County. Sheet: 6, 7, 11), Szt. Gen. WP, Warszawa.

[ZTSG] Zarząd Topograficzny Sztabu Generalnego (Topographical Board of the General Staff), 1987, Wojskowa mapa topograficzna 1:50 000. Arkusz: M-34-22-D Parczew, M-34-24-C Urszulin, M-34-24-C Ostrów Lubelski (Military topographic map 1:50 000. Sheet: M-34-22-D Parczew, M-34-24-C Urszulin, M-34-24-C Ostrów Lubelski), Szt. Gen. WP, Warszawa.

Żurek S., 1990, Związek procesu zatorfienia z elementami środowiska przyrodniczego wschodniej Polski (Relationship between the process of peating and elements of the natural environment of Eastern Poland), Rocz. Nauk. Roln. D 220: 1-174 (in English, Russian summary). 